\title{
PENGEMBANGAN MEDIA PEMBELAJARAN INTERAKTIF SMK TERHADAP EFEKTIF DAN EFISIENSI PEMBELAJARAN
}

\author{
Baharuddin \\ Teknologi Pendidikan, Pascasarjana Universitas Negeri Medan \\ baharuddin.bah@gmail.com
}

\begin{abstract}
Abstrak: Penelitian ini bertujuan mengembangkan multimedia pembelajaran interaktif terhadap Efektif dan Efisiensi Pembelajaran di SMK. Media pembelajaran pada penelitian ini menggunakan medel desain ADDIE. Adapun metode penelitian yang digunakan adalah metode Research and Developmetn $(R \& D)$. Data diperoleh melalui angket, dokumen dan tes. Analisis data sebagai dasar untuk mengembangkan media interaktif dengan menggunakan analisis kuantitatif. Hasil penelitian ini adalah (1) ahli media menunjukkan bahwa media pembelajaran yang dihasilkan 80,00\% dalam kategori baik, (2) ahli materi aspek isi/konten dalam media sebesar 91,58\% dalam kategori sangat baik, dan rata-rata hasil belajar 84,77 dalam kategori baik.
\end{abstract}

Kata Kunci: pengembangan, pembelajaran, interaktif, efektif dan efisien

Abstract: This study aims to develop a multimedia interactive learning for Effective and Efficient Learning in Vocational High School. Media learning in this study using ADDIE design medel. The research method used in this research is the method of Research and developmetn $(R \& D)$. Data were obtained through questionnaires, documents and tests. Analysis of the data as a basis for developing interactive media by using quantitative analysis. The results of this study were (1) media experts indicate that the learning media generated $80.00 \%$ in both categories, (2) the expert material aspect of the content / content in the media at $91.58 \%$ in the excellent category, and the average learning outcomes 84.77 in both categories.

Keywords: development, learning, interactive, effective and efficient

\section{PENDAHULUAN}

Perkembangan ilmu Pengetahuan dan teknologi yang semakin pesat dewasa ini perlu direspon oleh kinerja pendidikan yang professional dan bermutu tinggi. Kualitas serta perkem- bangan pendidikan yang demikian itu sangat dibutuhkan untuk mendukung terciptanya manusia yang cerdas dan terampil agar bisa bersaing secara terbuka di era globalisasi. Artinya pendidikan mulai dari sekolah dasar hingga tingkat lanjut perlu diperhatikan kualitasnya. Sesuai dengan ketentuan pada Undang-Undang No. 20 Tahun 2003 tentang Sistem Pendidikan Nasional, pendidikan kejuruan sebagai salah satu subsistem dari Sistem Pendidikan Nasional mempunyai tujuan utama menyiapkan tamatannya untuk memasuki dunia kerja.

Menurut Rayandra (2011: 92) pentingnya Media dalam upaya me- ningkatkan mutu pembelajaran Indonesia, tuntutan pasar global dan kurikulim berlandaskan paradigma baru pembelajaran. Namun ada dua permasalahan yang dihadapi sehubu- ngan dengan media pembelajaran dilembaga pendidik kita yaitu keterbatasan media, ketersediaan media pembelajaran di berbagai sekolah masih kurang dan belum merata. Ada sekolah yang sudah mampu menyedia- kan beragam media disertai dengan jumlah yang banyak. Dan ada juga yang masih belum memiliki jenis ragam dan jumlah media pembelajaran yang diperlukan. Dilihat dari segi tenaga pengajar juga ada yang menggunakan media yang beragam dan banyak secara maksimal, tetapi ada juga yang menggunakan masih minimal.

Media yang sering digunakan adalah medai cetak (diktat, modul, handout, buku teks, poster, majalah, surat kabar, dll.), sementara itu media sederhana yang tetap dimanfaatkan adalah papan tulis. Media audio visual (overhead transparancy, video/film, kaset audio, siaran TV/radio), dan medai elektronik (komputer, internet) masih belum secara optimal dimanfaatkan, meskipun dibeberapa tempat sudah mulai digunakan.

Media cetak adalah media yang sering digunakan dalam pembelajaran, karena cukup 
mudah dan dikenal luas di dunia pendidikan, serta mudah dikembangkan dan mudah dicari dari berbagai sumber. Akan tetapi kelemahan dari medai cetak itu sendiri adalah sangat tergantung nya pada verbal symbol (kata-kata) yang bersifat abstrak, yang menuntut peserta didik untuk memiliki kemampuan abstraksi yang tinggi, sehingga hal ini dapat menyulitkan mereka. Pada kondisi dimana jenis dan jumlah media pembelajaran yang tersedia bisa dikatakan kurang memadai, maka perlu dilakukan semacam pengembangan dan produksi media pembelajaran secara bertahap oleh pendidik sendiri, berkelompok, pengelola pendidik, dan atau melibatkan berbagai pihak.

Namun kenyataan yang ada di dunia pendidikan adalah banyak dari pendidik yang tidak mengembangkan media itu sendiri dengan berbagai alasan. Kemudian dalam hal pemanfaatan media, selain dari pada kreativitas pendidik yang dituntut tinggi, pertimbangan instruksional juga menjadi salah satu faktor yang menentukan. Pengembangan media pembelajaran sangat penting dalam dunia pendidikan, tak lain untuk mengatasi kekurangan dan keterbatasan media yang ada saat ini. Selain itu, media yang dirancang oleh pendidik itu sendiri dapat dengen tepat memenuhi sasaran dari yang sudah ditetapkan. Karena sudah pasti pendidik memahami kenutuhan, potensi sumber daya dan lingkungan masing-masing, terlebih lagi dapat mengasah kemampuan inovasi dan kreativitas dari pendidik itu sendiri yang dapat meningkatkan profesionalitas pendidik.

Pemanfaatan media pembelajaran juga dikaitkan erat dengan peningkatan kualitas pembelajaran tersebut. Pemanfaatan media yang dilakukan pendidik dalam proses pembelajaran diharapkan dapat menciptakan suasana belajar serta pengalaman belajar yang lebih bermakna, serta memperkaya pengalaman belajar siswa. Dengan demikian suasana belajar yang dulunya pasif, serta membosankan, dapat berubah menjadi aktif dengan disertai partisipasi para siswa yang menjadi lebih interaktif.

Sekolah Menengah Kejuruan (SMK) merupakan jenjang pendidikan yang berada pada menengah atas sesudah program pendidikan dasar sembilan tahun, dalam hirearki sistem pendidikan di Indonesia selain berfungsi menanamkan ketrampilan dan kemampuan agar dapat melanjutkan ke jenjang pendidikan yang lebih tinggi juga berfungsi untuk memberi bekal cukup kepada siswa dalam mengembangkan diri sesuai dengan potensi diri dan lingkungan yang ada. Dengan demikian, keberhasilan pembelajaran dalam pendidikan SMK sangat menentukan keberhasilan di jenjang dunia kerja.

Arief S. Sadiman (2009: 7) media adalah segala sesuatu yang dapat digunakan untuk menyalurkan pesan dari pengirim ke penerima sehinggga dapat merangsang pikiran, perasaan, minat serta perhatian siswa sedemikian rupa sehingga proses belajar terjadi. Kemudian menurut Purnamawati dan Eldarni (2001: 4), Media merupakan segala sesuatu yang dapat digunakan untuk menyalurkan pesan dari pengirim ke penerima sehingga dapat merangsang pikiran, perasaan, perhatian dan minat siswa sedemikian rupa sehingga terjadi proses belajarda.

Rayandra Asyar (2011: 8) bahwa media pembelajaran dapat dipahami sebagai segala sesuatu yang dapar menyampaikan atau menyalurkan pesan dari suatu seumber secara terencana, sehingga terjadi lingkungan belajar yang kondusif dimana penerimanya dapat melakukan proses belajar mengajar secara efisien dan efektif. Sehingga materi pembelajaran lebih cepat diterima siswa dengan utuh serta menarik minat siswa untuk belajar lebih lanjut.

Hamdani dalam Cut Muti (2012) mengemukakan bahwa media pembelajaran adalah bahan, alat, atau teknik yang digunakan dalam kegiatan belajar mengajar dengan maksud agar proses interaksi komunikasi edukasi dengan guru dan siswa dapat berlangsung secara tepat guna dan berdaya guna. Menurut Musfiqon (2012: 28) mendefinisikan media pembelajaran sebagai alat bantu berupa fisik maupun nonfisik yang sengaja digunakan sebagai alat perantara antara guru dan siswa dalam memahami materi pembelajaran agar lebih efektif dan efisien.

Dengan desain pembelajaran yang kreatif maka diharpkan proses pembelajaran menjadi inovatif, menarik, lebih interatif, lebih efektif, kualitas belajar belajar siswa dapat ditingkatkan, proses belajar mengajar dapat dilakukan dimana saja dan kapan saja, dan sikap dan minat belajar belajar siswa dapat ditingkatkan. Niken dan Haryanto (2010: 25) mengatakan bahwa multimedia interaktif adalah suatu multimedia yang dilengkapi dengan alat pengontrol yang dapat dioperasikan oleh pengguna sehingga pengguna dapat memilih 
apa yang dikehendakinya untuk proses selanjutnya. Niken dan haryanto (2010: 11) mengemukakan bahwa multimedia merupakan perpaduan antara berbagai media (format file) yang berupa teks, gambar (vector atau bitmap), grafik, sound, animasi, video, interaksi, dan lain-lain yang telah dikemas menjadi file digital (komputerisasi), digunakan untuk menyampaikan pesan kepada publik Niken dan Haryanto (2012: 12) manfaat multi media yaitu: (1) Pengenalan teknologi informasi dan komunikasi kepada siswa, (2) Memeberikan pengalaman baru dan meyenangkan baik bagi guru itu sendiri maupun siswa, (3) Mengejar ketertinggalan pengetahuan tentang Iptek di bidang pendidikan, (4) Pemanfaatan multimedia dapat membangkitkan motivasi belajar para pembelajar,(5) Multimedia dapat digunakan untuk membantu pembelajar membentuk model mental yang akan memudahkannya memahami suatu konsep, (6) Mengikuti perkemba- ngan Ipteks.

Multimedia interaktif ditujukan untuk membantu pendidik dalam penyampaian materi dan membantu siswa terlibat dalam proses pembelajaran dalam memahami materi yang diajarkan.

Hasil penelitian Vernon Magnesen dalam Nurhajati (2008: 25), persentase hasil daya ingat dari jenis kegiatan belajar yang dilakukan disajikan sebagai berikut.

\section{Tabel. 1 Tabel Persentasi Daya Ingat}

\begin{tabular}{|l|c|}
\hline \multicolumn{1}{|c|}{ Kegiatan Belajar } & $\begin{array}{c}\text { Persentasi Hasil } \\
\text { Daya Ingat (\%) }\end{array}$ \\
\hline Membaca & 20 \\
\hline Mendengar & 30 \\
\hline Melihat & 40 \\
\hline Mengucapkan & 50 \\
\hline Melakukan & 60 \\
\hline $\begin{array}{l}\text { Melihat, } \\
\text { mengucapkan, } \\
\text { mendengar, dan } \\
\text { melakukan }\end{array}$ & 90 \\
\hline
\end{tabular}

Dengan desain pembelajaran yang kreatif maka diharpkan proses pembelajaran menjadi inovatif, menarik, lebih interatif, lebih efektif, kualitas belajar belajar siswa dapat ditingkatkan, proses belajar mengajar dapat dilakukan dimana saja dan kapan saja, dan sikap dan minat belajar belajar siswa dapat ditingkatkan.
Kriteria untuk menilai multimedia interaktif, yaitu: (1) kemudahan navigasi, (2) kandungan kognisi. (3) presentasi informasi, (4) integrasi media, (5) estetika, (6) fungsi secara keseluruhan.

Lulusan SMK terbukti banyak yang belum mampu menjadi lulusan yang memiliki keahlian di bidangnya dalam hal kejuruan, seperti apa yang telah direncanakan sebelumnya, baik keinginan orang tua maupun dengan apa yang terdapat didalam kurikulum. Diantaranya lulusan SMK memiliki prestasi atau hasil belajar yang rendah. Berbicara mengenai prestasi, maka tidak lepas dari hasil belajar siswa, karena dari hasil belajar merupakan prestasi. Kurangnya pengusaan kom- petensi belajar adalah suatu proses usaha yang dilakukan seseorang untuk melakukan perubahan tingkah laku yang baru secara keseluruhan, sebagai hasil pengalamannya sendiri dalam interaksi dengan lingkunganya. Trianto (2009: 9) belajar adalah adanya perubahan tingkah laku karena adanya sutu pengalaman. Perubahan tingkah laku tersebut dapat berupa perubahan keterampilan, kebiasaan, sikap, pengetahuan, pemahaman, dan apresiasi. Adapun pengalaman dalam proses belajar ialah bentuk interaksi antara individu dengan lingkungan.

Hamalik (2010: 36) mengungkap- kan aspek-aspek yang terlihat dalam perubahan tingkah laku adalah: (1) pengetahuan; (2) pengertian; (3) kebiasaan; (4) keterampilan; (5) apresiasi; (6) emosial; (7) hubungan sosial; (8) jasmani; (9) etis atau budi pekerti; (10) sikap. Sementara Arief S. Sadiman (2009: 2) menyatakan belajar adalah suatu proses yang kompleks yang terjadi pada semua orang dan berlangsung seumur hidup, sejak dia masih bayi hingga keliang lahat nanti. Salah satu pertanda bahwa seseorang telah belajar adalah adanya perubahan tingka laku dalam dirinya. Perubahan tingkah laku ini menyangkut baik perubahan yang bersifat pengetahuan (kognitif) dan kerampilan (psikomotorik) maupun yang menyangkut nilai dan sikap(afektif).

Slameto (2003: 3) ciri-ciri perubahan tingkah laku dalam pengertian belajar adalah sebagai berikut: (1) perubahan yang terjadi secara sadar, (2) perubahan dalam belajar bersifat kontiniu dan fungsional, (3) perubahan dalam belajar bersifat positif dan aktif, (4) perubahan dalam belajar bukan bersifat sementara (5) perubahan dalam belajar 
bertujuan atau terarah, (6) perubahan mencakup seluruh aspek tingkah laku

Perubahan yang diperoleh seseorang setelah melalui suatu proses belajar meliputi perubahan keseluruhan tingkah lakuPengertian Pembelajaran

Menurut Benny (2009: 17) pembelajaran adalah proses yang sengaja dirancang untuk menciptakan terjadinya aktivitas belajar dalam diri individu. Niken dan Haryanto (2010: 25) pembelajaran sebagai proses penciptaan lingkungan yang memungkinkan terjadinya proses belajar.

Kemudian Hamalik (2010: 57) mendefinisikan pembelajaran merupa- kan suatu kombinasi yang tersusun meliputi unsurunsur manusiawi, material, fasilitas, perlengkapan, dan prosedur yang saling mempengaruhi mencapai tujuan pembelajaran. Untuk mengatasi efektifitas dan efisienya proses pembelajaran maka salah satu solusi yang tepat adalah penggunaan multimedia interaktif dalam pembelajaran.

Berdasarkan uraian di atas maka tujuan penelitian yang akan dicapai adalah mengembangkan multi media interaktif demi tercapainya pembelaja-ran yang efektif dan efisien dan hasil belajar yang optimal.

\section{METODE}

Penelitian dilakukan di SMK Negeri 2 Tameang dimulai dari bulan Oktober sampai dengan Desember 2013. Objek penelitian adalah Instalasi Listrik Penerangan Bangunan Sederhana. Subjek penelitian meliputi 29 siswa kelas XI Teknik Instalasi Listrik SMK Negeri 2 Tameang.

\section{a. Metode Penelitian dan Pengembangan}

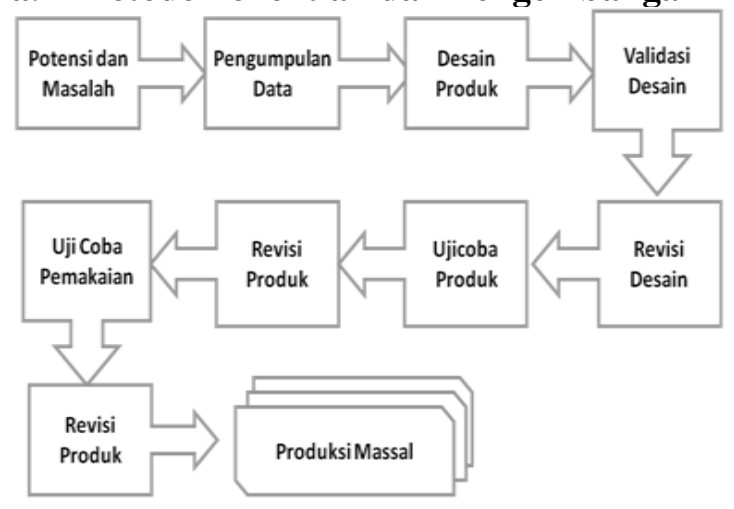

Gambar 1. Langkah-langkah Penggunaan Metode Research and Development (Sugiyono 2009:409)
Langkah-langkah Penelitian dan Pengembangan

1. Potensi dan Masalah

Penelitian berangkat dari adanya potensi dan masalah yang ada. Potensi merupakan segala sesuatu yang bila didaya gunakan memiliki nilai tambah.

2. Mengumpulkan Informasi

Setelah potensi dan masalah dapat ditunjukkan secara faktual dan update, maka selanjutnya perlu dikumpulkan berbagai informasi yang dapat digunakan sebagai bahan untuk perencanaan produk tertentu yang diharapkan dapat mengatasi permasalahan tersebut.

3. Desain Produk

Produk yang dihasilkan dalam penelitian Research and Development bermacammacam. Dalam bidang teknologi, orientasi produk teknologi yang dapat dimanfaatkan untuk kehidupan manusia adalah produk yang berkualitas, hemat energi, menarik, harga murah, bobot ringan, ergonomis, dan bermanfaat ganda (contoh komputer canggih yang berfungsi ganda, pengetikan, gambar, sebagai TV, dll.). dalam bidang pendidikan, produk-produk yang dihasilkan melalui penelitian $\mathrm{R} \quad \& \quad \mathrm{D}$ diharapkan dapat meningkatkan produktivitas pendidikan, yaitu lulusan yang jumlahnya banyak, berkualitas, dan relevan dengan kebutuhan.

4. Validasi Desain

Validasi desain merupakan proses kegiatan untuk menilai rancangan produk, dalam hal ini metode mengajar baru secara rasional akan lebih efektif dari yang lama atau tidak. Validasi produk dilakukan oleh beberapa ahli pakar atau tenaga ahli yang sudah berpengalamann untuk menilai produk baru yang dirancang tersebut. Setiap pakar diminta untuk menilai desain tersebut, sehingga selanjutnya dapat diketahui kelemahan dan kekurangan produk.

5. Uji coba pemakaian, penelitian ini dilakukan hanya sampai langkah ke 5

\section{b. Perancangan dan Pembuatan Produk}

Dalam penelitian ini, perancangan serta pembuatan produk menggunakan pembelajaran model instruksional ADDIE. Pembelajaran model ADDIE merupakan pembelajaran yang efektif dan efesien serta prosesnya bersifat interaktif, dimana hasil evaluasi setiapa fase dapat membawa pengembangan pembelajaran ke fase sebelumnya. Hasil akhir 
dari suatu fase merupakan produk awal bagi fase berikutnya.

Model ADDIE adalah jembatan antara peserta didik, materi, dan semua bentuk media, berbasis teknologi. Model addie didasarkan pada lima proses belajar bahwa:

- Analysis (analisa)

- Design (disain / perancangan)

- Development (pengembangan)

- Implementation (implementasi/eksekusi)

- Evaluation (evaluasi/ umpan balik

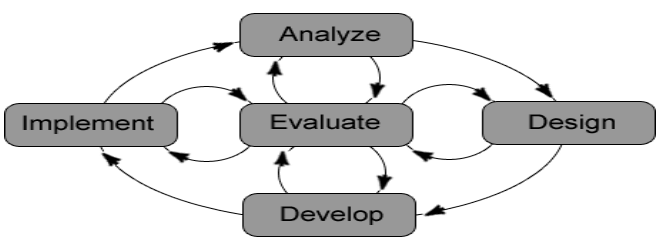

Gambar 2. Model Desain Pembelajaran ADDIE

\section{Langkah-langkah ADDIE sebagai berikut: Analisis (analysis)}

Tahap analisis merupakan suatu proses mendefinisikan apa yang akan dipelajari oleh peserta belajar, yaitu melakukan needs assessment (analisis kebutuhan), mengidentifikasi masalah (kebutuhan), dan melakukan analisis tugas (task analysis). Oleh karena itu, output yang akan kita hasilkan adalah berupa karakteristik atau profile calon peserta belajar, identifikasi kesenja-ngan, identifikasi kebutuhan dan analisis tugas yang rinci didasarkan atas kebutuhan.

\section{Desain (Design)}

Tahap ini dikenal juga dengan istilah membuat rancangan (blue-print). Ibarat bangunan, maka sebelum dibangun gambar rancang bangun (blue-print) diatas kertas harus ada terlebih dahulu. Apa yang kita lakukan dalam tahap desain ini? Pertama merumuskan tujuan pembelajaran yang SMAR (spesifik, measurable, applicable, dan realistic).

Selanjutnya menyusun tes, dimana tes tersebut harus didasarkan pada tujuan pembelajaran yag telah dirumuskan tadi. Kemudian tentukanlah strategi pembelajaran yang tepat harusnya seperti apa untuk mencapai tujuan tersebut. Dalam hal ini ada banyak pilihan kombinasi metode dan media yang dapat kita pilih dan tentukan yang paling relevan. Disamping itu, pertimbangkan pula sumber-sumber pendukung lain, semisal sumber belajar yang relevan, lingkungan belajar yang seperti apa seharusnya, dan lain-lain. Semua itu tertuang dalam sautu dokumen bernama blue-print yang jelas dan rinci.

\section{Pengembangan (Development)}

Pengembangan adalah proses mewujudkan blue-print alias desain tadi menjadi kenyataan. Artinya, jika dalam desain diperlukan suatu software berupa multimedia pembelajaran, maka multimedia tersebut harus dikembangkan. Atau diperlukan modul cetak, maka modul tersebut perlu dikembangkan. Begitu pula halnya dengan lingkungan belajar lain yang akan mendukung proses pembelajaran semuanya harus disiapkan dalam tahap ini. Satu langkah penting dalam tahap pengembangan adalah uji coba sebelum diimplementasikan. Tahap uji coba ini memang merupakan bagian dari salah satu langkah ADDIE, yaitu evaluasi. Lebih tepatnya evaluasi formatif, karena hasilnya digunakan untuk memperbaiki sistem pembelajaran yang sedang kita kembangkan.

\section{Implementasi (Implementation)}

Implementasi adalah langkah nyata untuk menerapkan sistem pembelajaran yang sedang kita buat. Artinya, pada tahap ini semua yang telah dikembangkan diinstal atau diset sedemikian rupa sesuai dengan peran atau fungsinya agar bisa diimplementasikan. Misal, jika memerlukan software tertentu maka software tersebut harus sudah diinstal. Jika penataan lingkungan harus tertentu, maka lingkungan atau seting tertentu tersebut juga harus ditata. Barulah diimplementasikan sesuai skenario atau desain awal.

\section{Evaluasi (Evaluation)}

Evaluasi adalah proses untuk melihat apakah sistem pembelajaran yang sedang dibangun berhasil, sesuai dengan harapan awal atau tidak. Sebenarnya tahap evaluasi bisa terjadi pada setiap empat tahap di atas. Evaluasi yang terjadi pada setiap empat tahap diatas itu dinamakan evaluasi formatif, karena tujuannya untuk kebutuhan revisi. Misal, pada tahap rancangan, mungkin kita memerlukan salah satu bentuk evaluasi formatif misalnya review ahli untuk memberikan input terhadap rancangan yang sedang kita buat. Pada tahap pengembangan, mungkin perlu uji coba dari produk yang kita kembangkan atau mungkin perlu evaluasi kelompok kecil dan lain-lain. 


\section{Teknik Pengumpulan Data}

Untuk mendapatkan data secara tepat maka instrumen dengan menggunakan angket dan tes

Angket yang diberikan dibuat secara berstruktur dengan bentuk pertanyaanpertanyaan terbuka (open ended) untuk mendapatkan informasi kebutuhan yang mendukung teori, informasi kebutuhann untuk pengembangan model, informasi. Guna mengetahui apakah siswa dapat menggunakan media pembelajaran interaktif serta penilaian atas kualitas dari media interaktif yang diberikan.dan tes untuk mengukur hasil belajar siswa

\section{Teknik Analisis Data}

Setelah data diperoleh, selanjutnya adalah menganalisa data tersebut. Penelitian ini lebih menitik beratkan pada keefektifan produk yang dirancang sebagai media pembelajaran pada mata diklat Instalasi Listrik Penerangan Bangunan Sederhana, sehingga data dianalisis dengan baik. Untuk menganalisis data dari angket, dilakukan langkah-langkah berikut: (1) Angket yang telah diisi responden, diperiksa kelengkapan jawabannya, kemudian disusun sesuai dengan kode responden, (2) Mengkuantitatifkan pertanyaan dengan memberikan skor sesuai dengan bobot yang telah ditentukan sebelumnya, (3)Membuat tabulasi data, (4)Menghitung presentase dari tiap-tiap sub variabel dengan rumus sebagai berikut:

$$
\begin{gathered}
P_{(s)}=S_{\boldsymbol{N}} \boldsymbol{x} \mathbf{1 0 0} \% \\
\text { Dimana: } \\
\mathrm{P}=\text { Presentase Sub Variabel } \\
\mathrm{S}=\text { Jumlah Skorr tiap Variabel } \\
\mathrm{N}=\text { Jumlah Skor Maksimum }
\end{gathered}
$$

Dari presentase yang diperoleh kemudian ditransformasikan kedalam tabel .2 berikut ini:

\section{Tabel 2. Interval Kriteria Penilaian}

\begin{tabular}{|c|l|l|}
\hline No & \multicolumn{1}{|c|}{ Interval } & \multicolumn{1}{|c|}{ Kriteria } \\
\hline 1 & $\begin{array}{l}81 \% \leq \text { skor } \geq \\
100 \%\end{array}$ & $\begin{array}{l}\text { Sangat Baik atau } \\
\text { Sangat Setuju }\end{array}$ \\
\hline 2 & $\begin{array}{l}61 \% \leq \text { skor } \geq 80 \\
\%\end{array}$ & Baik atau Setuju \\
\hline 3 & $\begin{array}{l}41 \% \leq \text { skor } \geq 60 \\
\%\end{array}$ & Cukup \\
\hline 4 & $\begin{array}{l}21 \% \leq \text { skor } \geq 40 \\
\%\end{array}$ & $\begin{array}{l}\text { Kurang Baik } \\
\text { atau Kurang } \\
\text { Setuju }\end{array}$ \\
\hline
\end{tabular}

\begin{tabular}{|l|l|l|}
\hline 5 & $\begin{array}{l}0 \% \leq \text { skor } \geq 20 \\
\%\end{array}$ & $\begin{array}{l}\text { Tidak Baik atau } \\
\text { Tidak Setuju }\end{array}$ \\
\hline
\end{tabular}

(Sumber: Panduan Evaluasi Universitas Negeri Medan, 2012)

\section{HASIL PENELITIAN}

Analisis kebutuhan, merupakan langkah yang diperlukan untuk menentukan kemampuan-kemampuan atau kompetensi yang perlu dipelajari oleh siswa untuk meningkatkan prestasi belajar.

Dalam penelitian ini, peneliti hanya fokus kepada analisis kebutuhan pembelajaran instalasi listrik penerangan bangunan sederhana, dan hasil analisis yang dilakukan adalah sebagai berikut: a) Penyampaian materi pembelajaran menggunakan metode ceramah membuat siswa kurang aktif sehingga siswa cepat mengalami kejenuhan, bersikap pasif sehingga siswa cepat mengalami kejenuhan, bersikap pasif dan mengakibatkan berkurangnya perhatian siswa dalam proses belajar mengajar. Sehingga pada akhirnya akan berdampak kepada hasil belajar yang kurang optimal, b)Responden menyatakan perlunya penggunaan media interaktif yang mampu mempermudah siswa dalam proses pembelajaran instalasi listrik penerangan bangunan sederhana, dan hendaknya media tersebut dapat digunakan juga untuk praktek secara virtual sehingga siswa dapat mengerti secara teori kemudian diperkuat secara praktek tentang materi yang disampaikan, c)Menurut responden, materi instalasi listrik penerangan bangunan sederhana perlu diketahui secara baik, sebab materi tersebut merupakan materi dasar bagi siswa untuk mengikuti pembelajaran selanjutnya.Dan materi instalasi listrik materinya kebanyakan bentuk rangkaian sehingga perlu media interaktif yang memudahkan siswa mengaplikasikan rangkaian kedalam bentuk instalasi nyata pada praktikum.

Berdasarkan hasil analisis kebutuhan di atas, maka peneliti merancang sebuah media pembelajaran baru yaitu multimedia interaktif yang dikemas dalam bentuk CD interaktif dengan spesifikasi sebagai berikut: (a)Tampilan menarik, (b)Mudah digunakan, (c)Dapat digunakan di komputer berspesifikasi rendah, (d)Dilengkapi dengan software pendukung, (e)Materi sesuai dengan kebutuhan belajar dan mudah dimengerti (dilengkapi dengan simulasi, animasi, audio, video, serta gambar).

$$
\text { Desain } \quad \mathrm{CD} \text { interaktif }
$$
mempertimbangkan kepada (a) Pengguna, CD 
interaktif ini dibuat untuk mempermudah proses belajar dan meningkatkan minat serta hasil belajar siswa SMK jurusam TITL; (b) Peralatan output, karena $\mathrm{CD}$ interaktif akan digunakan secara mandiri oleh siswa maka diperlukan format yang kompatibel terhadap jenis komputer yang akan digunakan oleh siswa baik dirumah maupun di rental komputer serta warung internet; (c) Gambar, CD interaktif ini disertai dengan gambar seperti pada latar belakang dan ilustrasi; (d) Audio, untuk audio yang digunakan pada $\mathrm{CD}$ interaktif ini tidak terlalu banyak dengan alasan suara dapat mengganggu konsentrasi belajar dan jika diperlukan audio untuk penyegaran siswa dapat menggunakan audio yang terdapat pada komputer yang digunakan; (e) Animasi, animasi ditampilkan sesuai dengan materi yang dibahas sehingga siswa dapat melihat ilustrasi bergerak dari materi yang dipelajari; (f) Simulasi dan Video, simulasi disajikan dalam bentuk video dimana siswa dapat menekan tombol play untuk menjalankan video tersebut; (g) Form Jawaban, form jawaban disediakan pada menu latihan di media pembelajaran tersebut.

Desain, pengembangan dan implementasi media pembelajaran yang ditujukan kepada siswa SMK TITL SMK Negeri 2 Tameang dibuat dalam CD interaktif, dibuat dalam bentuk animasi dan simulasi dan dikerjakan menggunakan microsoft office power point dan di publish menjadi bentuk flash dan dikemas dalam bentuk CD. Media pembelajaran ini dibangun dalam bentuk $C D$ bertujuan untuk mempermudah siswa dalam belajar, dimana media dalam bentuk CD dapat digunakan tidak hanya disekolah saja, tetapi juga dapat digunakan dirumah atau bahkan memanfaatkan fasilitas-fasilitas umum seperti warnet dan rental computer. Pemanfaatan bentuk game $\mathrm{CD}$ ini dapat mendorong siswa yang pergi ke warnet untuk bermain game online ataupun facebook dapat sekaligus mempelajari bahan belajar yang termuat didalam CD interaktif ini. Dalam desain dan pengembangan $\mathrm{CD}$ interaktif ini faktor-faktor berikut menjadi perhatian utama, yaitu: (1) penyajian informasi, (2) kegunaan media, (3) kemudahan penggunaan, (4) kemanfaatan. Materi yang termuat di dalam media masih sebatas kepada beberapa sub kompetesnsi yang tetap saling berkaitan, sehinggan walaupun hanya terdiri dari beberapa sub kompetensi media tetap memiliki nilai pengetahuan yang dibutuhkan untuk mencapai tujuan pembelajaran yang sesuai dengan kurikulum. Keterbatasan materi ini dikarenakan keterbatasan waktu dalam penelitian.

Materi dalam CD interaktif terdiri dari (1) Petunjuk penggunaan, (2) Tujuan umum, (3) Materi, (4) Simulasi, (5) Aplikasi, (6) Tes.

Setelah desain tampilan dan isi dari CD interaktif telah selesai dilakukan, tindakan selanjutnya adalah mengerjakan pembuatan $\mathrm{CD}$ menjadi wujud nyata. Pengerjaan CD interaktif dimulai dari memilih background dan menempatkan tombol-tombol sesuai dengan desain yang telah ditentukan sebelumnya agar CD interaktif dapat digunakan seperti yang diinginakan

Setelah produk diselesaikan, selanjutnya dilakukan validasi oleh Ahli Media dan ahli materi. Hasil angket yang disebarkan dan diisi oleh responden akan dianalisis.

Hasil validasi media oleh ahli media diketahui bahwa media mendapatkan penilaian dengan rata-rata $80,00 \%$ kategori baik. Dengan demikian, pengembangan media ini telah berhasil mencapai tujuan akhir dari penelitian yaitu melihat respon ahli apakah media yang dikembangkan dapat/layak digunakan sebagai media pembelajaran.

Hasil validasi ahli materi diketahui bahwa media mendapatkan penilaian dengan 91,58 kategori sangat baik. Dengan demikian, pengembangan media ini telah berhasil mencapai tujuan akhir dari penelitian yaitu melihat respon ahli apakah media yang dikembangkan dapat / layak digunakan sebagai media pembelajaran. Pengujian terhadap siswa

Setelah proses desain, pembua-tan, implementasi dan evaluasi selesai dilakukan dan CD interaktif sudah siap untuk digunakan, selanjutnya perlu dilakukan desiminasi produk. Desiminasi CD interaktif dimaksudkan untuk memperkenalkan produk sekaligus menguji efektifitas CD interaktif dalam memengaruhi proses dan hasil belajar siswa. Desiminasi CD interaktif ini dilakukan dalam II tahap, yaitu:

\section{Pengujian tahap I}

Pengujian tahap I dilakukan terhadap 10 orang siswa TITL kelas XI. Uji coba dilakukan untuk mendapatkan informasi penggunaan $\mathrm{CD}$ interaktif dalam proses pembelaja-ran respon siswa. Setiap siswa diberikan $\mathrm{CD}$ interaktif, kemudian siswa menggunakan $\mathrm{CD}$ interaktif secara mandiri. Setelah menggunakan CD interaktif ini, siswa memberikan komentar pada angket yang 
disediakan dan mengerjakan tes. Adapun aspekaspek penilaian yang dikomentari oleh siswa dapat dilihat pada table.5 sebagai berikut:

Tabel 3. Hasil Angket CD Interaktif terhadap Siswa pada Pengujian I

\begin{tabular}{|c|c|c|c|c|c|c|}
\hline & \multicolumn{2}{|c|}{$\begin{array}{c}\text { Daya } \\
\text { Tarik }\end{array}$} & \multicolumn{2}{c|}{$\begin{array}{c}\text { Tingkat } \\
\text { Kesulitan }\end{array}$} & \multicolumn{2}{c|}{$\begin{array}{c}\text { Manfaa } \\
\text { t }\end{array}$} \\
\cline { 2 - 7 } & $\mathrm{A}$ & $\mathrm{B}$ & $\mathrm{A}$ & $\mathrm{B}$ & $\mathrm{A}$ & $\mathrm{B}$ \\
\hline $\begin{array}{c}\text { Jumlah } \\
\text { siswa yang } \\
\text { menyatakan } \\
\text { "Ya" }\end{array}$ & 9 & 10 & 10 & 10 & 9 & 10 \\
\hline $\begin{array}{c}\text { Jumlsh } \\
\text { siswa yang } \\
\text { menyatakan } \\
\text { "Tidak" }\end{array}$ & 1 & - & - & - & 1 & - \\
\hline
\end{tabular}

Pada Tabel.3 setiap komponen dibagi menjadi 2 bagian lagi yaitu a dan $b$ yang merupakan aspek-aspek yang dinilai setiap komponen. Respon yang diberikan siswa terhadap media dengan baik.

\section{Revisi Tahap I}

Respon yang diperoleh dari pengujian tahap I adalah siswa yang menyukai media pembelajaran tersebut dengan ditunjukkan pada angket yang diberikan kepada siswa dengan hasil yang baik.

\section{Pengujian Tahap II}

Setelah mempertimbangkan hasil pengujian selanjutnya dilakukan pengujian lagi dan melibatkan lebih banyak siswa sebagai responden, yaitu 29 orang siswa TITL. Setelah pengarahan diberikan kemudian siswa dipersilahkan menggunakan $\mathrm{CD}$ interaktif secara mandiri. Setelah menggunakan CD interaktif ini, siswa memberikan komentar pada angket yang disediakan dan melakukan tes. Komentar siswa pada pengujian tahap II dapat dilihat pada tabel. 4 berikut:

Tabel 4. Hasil Angket CD Interaktif pada Pengujian Tahap II

\begin{tabular}{|c|c|c|c|c|c|c|}
\hline \multirow{2}{*}{} & \multicolumn{2}{|c|}{$\begin{array}{c}\text { Daya } \\
\text { Tarik }\end{array}$} & \multicolumn{2}{c|}{$\begin{array}{c}\text { Tingkat } \\
\text { Kesulitan }\end{array}$} & \multicolumn{2}{c|}{ Manfaat } \\
\cline { 2 - 7 } & A & B & A & B & A & B \\
\hline $\begin{array}{c}\text { Jumlah } \\
\text { siswa } \\
\text { yang } \\
\text { menyataka } \\
\text { n "Ya" }\end{array}$ & 28 & 29 & 28 & 29 & 28 & 27 \\
\hline $\begin{array}{c}\text { Jumlsh } \\
\text { siswa } \\
\text { yang } \\
\text { menyataka } \\
\text { n "Tidak" }\end{array}$ & 1 & - & 1 & - & 1 & 2 \\
\hline
\end{tabular}

Pada tabel .4 dapat dilihat respon yang diberikan siswa menunjukkan $\mathrm{CD}$ interaktif sangat disukai siswa sebagi media dalam proses pembelajaran. Hal tersebut sangat berpengaruh pada hasil tes yang dikerjakan oleh siswa yang menunjukkan hasil yang maksimal.

\section{Hasil Tes}

Hasil tes siswa pada pengujian tahap II menunjukkan rata-rata sebesar 84,77. Pengujian tahap II menunjukkan hasil yang sangat memuaskan, dimana CD interaktif sudah teruji efektivitas dan efisiensinya.

\section{PEMBAHASAN}

Berdasarkan hasil penelitian yang telah dilakukan, dan hasil angket yang disebarkan kepada ahli media dan ahli materi, maka penilaian multimedia

Ahli menyatakan penilaian terhadap aspek panduan adalah baik, berikut pembahasannya tertera pada tabel .5 dibawah ini:

Tabel 5. Hasil Validasi Ahli Terhadap Aspek Panduan

\begin{tabular}{|c|c|c|c|c|c|c|}
\hline \multirow{2}{*}{ No. } & \multirow{2}{*}{$\begin{array}{c}\text { Pernyataa } \\
\mathbf{n}\end{array}$} & \multicolumn{3}{|c|}{ Ahli } & \multirow{2}{*}{$\begin{array}{c}\text { Rata- } \\
\text { rata }\end{array}$} & \multirow{2}{*}{ Kategori } \\
\hline & & I & II & III & & \\
\hline 1 & $\begin{array}{l}\text { Petunjuk } \\
\text { penggunaa } \\
\text { n aplikasi } \\
\text { program }\end{array}$ & 4 & 5 & 5 & $93.33 \%$ & $\begin{array}{c}\text { Sangat } \\
\text { Baik }\end{array}$ \\
\hline 2 & $\begin{array}{l}\text { Kemudaha } \\
n \\
\text { penggunaa } \\
\text { n program }\end{array}$ & 4 & 5 & 5 & $93.33 \%$ & $\begin{array}{c}\text { Sangat } \\
\text { Baik }\end{array}$ \\
\hline 3 & $\begin{array}{l}\text { Struktur } \\
\text { dan } \\
\text { kepraktisa } \\
\text { n aplikasi } \\
\text { program }\end{array}$ & 4 & 4 & 4 & $80.00 \%$ & Baik \\
\hline
\end{tabular}

Aspek penilaian dalam aspek panduan adalah petunjuk penggunaan aplikasi dengan nilai rata-rata $93,33 \%$ dengan kategori sangat baik. Poin kedua penilaian adalah kemudahan penggunaan program dengan nilai rata-rata 93,33\% dengan kategori sangat baik. Poin ketiga penilaian adalah struktur dan kepraktisan aplikasi program dengan rata-rata $80 \%$ dalam kategori baik. Secara keseluruhan rata-rata penilaian terhadap aspek panduan adalah $87,5 \%$ atau dalam kategori sangat baik.

\section{Aspek isi/konten media}

Penilaian ahli terhadap aspek isi konten media menyatakan bahwa isi konten media sangat baik seperti terlihat pada tabel .6 sebagai berikut: 
Tabel 6. Hasil Validasi Ahli terhadap Aspek

\begin{tabular}{|c|c|c|c|c|c|c|}
\hline \multicolumn{7}{|c|}{ Isi/Konten } \\
\hline \multirow{2}{*}{$\begin{array}{l}\mathbf{N} \\
\mathbf{o .}\end{array}$} & \multirow{2}{*}{ Pernyataan } & \multicolumn{3}{|c|}{ Ahli } & \multirow{2}{*}{$\begin{array}{l}\text { Rata- } \\
\text { rata }\end{array}$} & \multirow{2}{*}{ Kategori } \\
\hline & & I & II & III & & \\
\hline 1 & $\begin{array}{l}\text { Kejelasan } \\
\text { pernyataan } \\
\text { tujuan } \\
\text { pembelajara } \\
\text { n }\end{array}$ & 5 & 5 & 4 & $93.33 \%$ & $\begin{array}{c}\text { Sangat } \\
\text { Baik }\end{array}$ \\
\hline 2 & $\begin{array}{l}\text { Kesesuaian } \\
\text { isi/bahan } \\
\text { dengan } \\
\text { tujuan }\end{array}$ & 4 & 5 & 4 & $86.67 \%$ & $\begin{array}{l}\text { Sangat } \\
\text { Baik }\end{array}$ \\
\hline 3 & $\begin{array}{l}\text { Kesesuaian } \\
\text { isi/bahan } \\
\text { dengan } \\
\text { kurikulum } \\
\text { yang } \\
\text { digunakan } \\
\end{array}$ & 4 & 4 & 4 & $80.00 \%$ & Baik \\
\hline 4 & $\begin{array}{l}\text { Petunjuk dan } \\
\text { panduan } \\
\text { aplikasi } \\
\text { penggunaan } \\
\text { isi/bahan }\end{array}$ & 4 & 5 & 5 & $93.33 \%$ & $\begin{array}{c}\text { Sangat } \\
\text { Baik }\end{array}$ \\
\hline 5 & $\begin{array}{l}\text { Paparan } \\
\text { konsep dan } \\
\text { batasan } \\
\text { tentang isi } \\
\text { bahan } \\
\end{array}$ & 4 & 5 & 5 & $93.33 \%$ & $\begin{array}{c}\text { Sangat } \\
\text { Baik }\end{array}$ \\
\hline 6 & $\begin{array}{l}\text { Pemberian } \\
\text { contoh dan } \\
\text { ilustrasi }\end{array}$ & 3 & 5 & 5 & $86.67 \%$ & $\begin{array}{c}\text { Sangat } \\
\text { Baik }\end{array}$ \\
\hline 7 & $\begin{array}{l}\text { Kemutakhira } \\
\mathrm{n} \text { isi/ bahan } \\
\text { yang } \\
\text { diasjikan }\end{array}$ & 4 & 4 & 4 & $80.00 \%$ & Baik \\
\hline 8 & $\begin{array}{l}\text { Kemudahan } \\
\text { memahami } \\
\text { bahasa yang } \\
\text { digunakan }\end{array}$ & 4 & 4 & 5 & $86.67 \%$ & $\begin{array}{c}\text { Sangat } \\
\text { Baik }\end{array}$ \\
\hline
\end{tabular}

Dalam aspek isi/konten media beberapa penilaian antara lain kejelasan pernyataan tujuan dengen nilai rata-rata $93,33 \%$ dalam kategori sangat baik, kesesuaian isi/bahan dengan tujuan dengan nilai $86,67 \%$ dalam kategori baik, kesesuaian isi/bahan dengan kurikulum yang digunakan dengan nilai $80 \%$ dalam kategori baik, petunjuk dan panduan aplikasi penggunaan isi/bahan dengan nilai 93,33\% dalam kategori sangat baik, kemudian paparan konsep dan batasan tentang isi bahan, pemberian contoh dan ilustrasi serta kemutakhiran isi/bahan yang disajikan dengan nilai masing-masing $86,67 \%$; 80\%; 86,67\% dalam kategori sangat baik, serta kemudahan memahami bahasa yang digunakan dengan nilai $86,67 \%$ dalam kategori sangat baik. Secara keseluruhan rata-rata penilaian aspek isi/konten media adalah $87,5 \%$ dalam kategori sangat baik.

\section{Aspek paparan}

Penilaian terhadap aspek paparan dalam media adalah sangat baik, seperti ditunjukkan pada table.7 sebagai berikut:

Tabel 7. Hasil Validasi Ahli terhadap Aspek Paparan

\begin{tabular}{|c|c|c|c|c|c|c|}
\hline \multirow{2}{*}{ No. } & \multirow{2}{*}{ Pernyataan } & \multicolumn{3}{|c|}{ Ahli } & \multirow{2}{*}{$\begin{array}{l}\text { Rata- } \\
\text { rata }\end{array}$} & \multirow{2}{*}{ Kategori } \\
\hline & & I & II & III & & \\
\hline 1 & $\begin{array}{l}\text { Kualitas } \\
\text { paparan } \\
\text { isi/bahan } \\
\text { yang } \\
\text { disajikan }\end{array}$ & 4 & 5 & 4 & $86.67 \%$ & $\begin{array}{c}\text { Sangat } \\
\text { Baik }\end{array}$ \\
\hline 2 & $\begin{array}{l}\text { Teknik dan } \\
\text { sistematika } \\
\text { penyajian } \\
\text { isi/bahan }\end{array}$ & 3 & 4 & 5 & $80.00 \%$ & Baik \\
\hline 3 & $\begin{array}{l}\text { Penggunaan } \\
\text { warna pada } \\
\text { tampilan } \\
\text { layar (screen) }\end{array}$ & 4 & 4 & 5 & $86.67 \%$ & $\begin{array}{c}\text { Sangat } \\
\text { Baik }\end{array}$ \\
\hline 4 & $\begin{array}{l}\text { Susunan teks } \\
\text { yang } \\
\text { digunakan }\end{array}$ & 4 & 5 & 4 & $86.67 \%$ & $\begin{array}{c}\text { Sangat } \\
\text { Baik }\end{array}$ \\
\hline 5 & $\begin{array}{l}\text { Susunan } \\
\text { grafik dan } \\
\text { gambar yang } \\
\text { disajikan }\end{array}$ & 3 & 5 & 4 & $80.00 \%$ & Baik \\
\hline 6 & $\begin{array}{l}\text { Kualitas } \\
\text { video/audio }\end{array}$ & 4 & 4 & 5 & $86.67 \%$ & $\begin{array}{l}\text { Sangat } \\
\text { Baik }\end{array}$ \\
\hline 7 & $\begin{array}{l}\text { Kemudahan } \\
\text { memahami } \\
\text { informasi } \\
\text { yang } \\
\text { disajikan }\end{array}$ & 4 & 5 & 4 & $86.67 \%$ & $\begin{array}{c}\text { Sangat } \\
\text { Baik }\end{array}$ \\
\hline 8 & $\begin{array}{l}\text { Penggunaan } \\
\text { tombol } \\
\text { pengarah/pen } \\
\text { gendali }\end{array}$ & 4 & 4 & 5 & $86.67 \%$ & $\begin{array}{c}\text { Sangat } \\
\text { Baik }\end{array}$ \\
\hline
\end{tabular}

Penilaian aspek paparan pada tiap poin adalah kualitas paparan isi/bahan yang disajikan serta teknik dan sistematika penyajian isi/bahan dengan nilai 86,67\%; 80\% dalam kategori baik, penggunaan warna pada tampilan layar (screen) dan, susunan teks yang digunakan dengan nilai $86,67 \%$ dalam kategori sangat baik, susunan grafik dan gambar yang disajikan dengan nilai $80 \% \%$ dalam kategori baik, kualitas video/audio, kemudahan memahami informasi yang disajikan, penggunaan tombol pengarah/pengendali dengan nilai $86,67 \%$ dalam kategori sangat baik. Secara keseluruhan rata-rata penilaian terhadap aspek paparan adalah $85 \%$ dalam kategori sangat baik.

Berdasarkan hasil penelitian yang telah dilakukan, maka media pembelajaran seperti ini efektif sebagai media pembelajaran pada mata pelajaran Memasang Instalasi Listrik Penerangan Bangunan Sederhana. Penggunaanya relatif mudah dan sederhana, hanya tinggal memasukkan $\mathrm{CD}$ tersebut melalui 
DVD atau CD drive pada laptop ataupun komputer dan menampilkan melalui layar proyektor ataupun juga melalui komputer, sambil mengikuti praktek secara langsung seperti yang tersaji didalam media pembelajaran tersebut.

Berdasarkan hasil angket yang telah disebarkan kepada evaluator, maka media pembelajaran ini telah memenuhi syarat dalam kategori Sangat Baik/ Sanngat Setuju. Media pembelajaran ini seluruhnya menggu-nakan bahasa Indonesia, sehingga tidak terdapat kendala dalam hal bahasa.

\section{PENUTUP}

Berdasarkan hasil validasi dari ahli media rata-rata $80,00 \%$, ahli materi rata-rata $91,58 \%$ dan hasil tes siswa rata-rata 84,77 , maka disimpulkan multimedia pembelajaran interaktif yang dikembangkan layak dan efektif digunakan sebagai media pembelajaran khususnya pada mata diklat Memasang Instalasi Penerangan Bangunan Sederhana.

Dalam pembuatan media pem-belajaran berbasis multimedia interaktif juga dapat meningkatkan ketrampilan guru dalam membuat suatu pembelaja-ran yang lebih menarik bagi siswa. Sehingga siswa lebih tertarik lagi dalam belajar, dikarenakan mereka belajar dengan cara yang lebih menarik.

\section{DAFTAR PUSTAKA}

Arief, Sadiman. (2009). Media Pendidikan. Jakarta: PT. Raja Grafindo Persada.

Andikafisma'sBlog. (2012). Pengertian Multimedia, http://andikafisma. wordpress.com /multimedia/ (diakses 10 Januari 2014)

Benny A. Priyadi (2009). Model-Model Desain Sistem Pembelejaran. Jakarta: PPS-UNJ

Dadang Supriatna, dan Mochamad Mulyadi. (2009). Konsep Dasar Desain Pembelejaran. PPPPTK TK.

Hamalik, Oemar. (2010). Proses Belajar Mengajar. Jakarta: Bumi Aksara

H.M. Musfiqon. (2012). Pengembangan Media dan Sumber Pembelajaran. Jakarta: Prestasi Pustaka.

http://digilib.unimed.ac.id/public/UNIMEDUndergraduate-22779-BAB\%20II.pdf (diakses 4 April 2014)

Niken Ariani dan Haryanto. (2010). Pembelajaran Multimedia di Sekolah. Jakarta: Prestasi Pustaka.
Rayandra, Asyhar. (2011). Kreatif Mengembangkan Media Pembelajaran. Jakarta: GP. Press

Sanaky, Hujair. (2011). Media Pembelajaran. Yogyakarta: Kaukaba

Sanjaya, Wina. (2008). Strategi Pembelajaran. Jakarta: Kencana

Slameto. (2003). Belajar dan Faktor-faktor yang Mempengaruhinya. Jakarta: Rineks Cipta

Solihin, M. Dani. (2012). Desain Pembelajaran Berbasis Multimedia Interaktif Pada Mata Diklat Mengoperasikan Sistem Pengendali Elektromagnetik Di SMK Negeri 1 Percut Sei Tuan. Medan: UNIMED. Skripsi Tidak Dipublikasikan

Sugiyono. (2009). Metode Penelitian Pendidikan. Bandung: Alfabeta Bandung

Sriadhi, (2012) Instrumen Ukur Kelayakan Courseware Multimedia Learning. Centre for Instructional Technology and Multimedia, USM

Suprayatna, Mulyadi, (2012). Konsep Dasar Desain Pembelajaran, Bahan Ajar untuk Diklat E-Training PPPPTKTK dan $L B$ (online) dalam (http://www.tkplb.org/documents/ctrainin g\%20media\%20pembelajaran/3.Konsep_ Dasar_Desain_Pembelajaran.pdf) diakses 20 September 2012

Undang Undang RI Nomor 20 Tahun 2003 Tentang Sistem Pendidikan Nosional. Jogjakarta : Media Wacana Press. Diakses pada tanggal 24 